\title{
1 English in Scandinavia: Monster or Mate? Sweden as a Case Study
}

\author{
Catrin Norrby
}

\section{Introduction}

When Swedish Crown Princess Victoria and Prince Daniel recently became parents, the prince explained his feelings at a press conference, hours after their daughter was born, with the following words (cited from Svenska Dagbladet, 23 February 2012):

Mina känslor är lite all over the place. När jag gick frän rummet så låg den lilla prinsessan på sin moders bröst och såg ut att ha det väldigt mysigt

[My feelings are a bit all over the place. When I left the room the little princess was lying on her mother's breast and seemed to be very cosy]

The use of English catchphrases and idioms in an otherwise Swedish language frame is not unusual and it is no exaggeration to say that English plays a significant role in contemporary Scandinavia. The following areas of use at least can be distinguished: (1) English taught as a school subject; (2) English used as a lingua franca; (3) English in certain domains; (4) English as an act of identity; and (5) English in the linguistic landscape.

The term 'Scandinavia' is used in this chapter as shorthand for Denmark, Norway and Sweden (where Scandinavian languages are spoken) as well as for Finland (which is part of the Scandinavian peninsula together with Sweden and Norway). English is taught as a mandatory subject in schools throughout Scandinavia, usually from Grade 3 or 4, meaning that school leavers normally have 9-10 years of English teaching. In recent years there has been an increase of CLIL (content and language integrated learning), where content subjects are taught in English (see, for example, Washburn, 1997). The availability of English instruction throughout the education 
system is a prerequisite for the generally high level of proficiency in English among Scandinavians (see below).

English is used as a lingua franca by Scandinavians for communication not only in international contexts but also nationally, as well as for interScandinavian communication. Danish, Norwegian and Swedish are often taken as examples of mutually intelligible languages, enabling speakers to use their native language in communication with their neighbours, sometimes referred to as semicommunication (Haugen, 1972). Recent studies, however, indicate that mutual intelligibility might be diminishing, as adolescents generally understand English better, and also display poorer understanding of the neighbour languages compared to their parents (Delsing \& Lundin Akesson, 2005). Turning to the national level, English is also used for communication within many domains, in particular in research and higher education, business and large companies, as well as in popular culture and advertising. In this chapter, the focus is on the domains of research and higher education.

In Scandinavia, code-switching between a national language and English is a phenomenon which has been particularly observed in young people's discourse. For example, Sharp (2001) found on average one codeswitch to English per minute among Swedish youths. Most of these codeswitches were unintegrated English language material in an otherwise Swedish frame, and were often made up of phrases from films, songs, advertising, and so on. Sharp (2001: 117) refers to these switches as 'the quoting game', where the speakers flag the shift to English by a change of voice quality or laughter. In other words, these code-switches can be interpreted as an act of identity where the speaker appeals to shared knowledge of global trends and in-group commonalities (see also Preisler, 2003 for similar results in a Danish context).

English in the linguistic landscape refers to the documentation of visible signs of English language use in a society, e.g. linguistic objects such as signs in the streets, in shops and service institutions. An important underpinning of linguistic landscaping is the understanding that public spaces are symbolically constructed by linguistic means (Ben-Rafael et al., 2010). In this chapter, we explore the extent of English presence in a large shopping mall in downtown Stockholm.

The points above are not discrete but overlapping categories. For example, use of English as a lingua franca clearly overlaps with its use in certain domains, and English as an act of identity encompasses not only spontaneous use in interaction: its use in the linguistic landscape can also often be interpreted as promoting a certain identity. Furthermore, the various points refer to practices at different levels in society. Some can best be described as forces from above (e.g. English in the education system, and in the domains of business or research) whereas others pertain to forces from below, at the grass-roots level (e.g. in private interactions, use in certain subcultures and 
music scenes). It has been argued that this combination of movements from both above and below accounts for the strong position English enjoys in Scandinavia (Preisler, 2003).

\section{English Language Skills and Attitudes to English Among Scandinavians}

In this section, the general level of English skills and attitudes to English among the Scandinavian population are outlined and compared to those of other Europeans.

\section{Skills and attitudes among high-school students}

In a study of English skills and attitudes among Grade 9 students in eight European countries - The Assessment of Pupils' Skills in English in Eight European Countries (Bonnet, 2002) - student results from Denmark, Finland, Norway, Sweden, Germany, the Netherlands, France and Spain were compared. The results were based on a random sample of 1500 students from each nation (with the exception of Germany where the sample was much smaller and therefore not included in the overview below). The test was the same for all countries, but with instructions in the national languages. It was part of a survey of foreign language skills carried out on behalf of the European network of policy makers for the evaluation of education systems. Four skills areas were tested through multiple-choice and gap-fills: listening and reading comprehension, language correctness and written production. Students were also asked to evaluate the level of difficulty of the test and to assess their own English skills. In addition to the test and self-evaluations, both students and their teachers were asked about their use of and attitudes to English.

The results for each skills area can be divided into three tiers, where the Scandinavian (including Finnish) students tend to appear to the left, with higher skills, whereas the southern Europeans appear to the right, with lower skills. Norway and Sweden appear in the top tier for all four skills, and for reading and correctness we also find Finland among the top performers, as outlined in Table 1.1.

The strong results for the Scandinavian students can no doubt be linked, in part, to their positive attitudes towards English. The highest scores in this regard were recorded for the Swedish students, where 96\% claimed to like English in general, followed by Denmark (90.2\%), Finland (89.6\%) and Norway (88.8\%), compared with an overall average of $79.9 \%$ for the seven countries. As many as $98 \%$ of the Swedish students said it was important to know English, again followed by the other Scandinavians: Denmark (96\%), Finland $(92.7 \%)$ and Norway $(91.6 \%)$. 
Table 1.1 English skills among Grade 9 students in seven European countries

\begin{tabular}{|c|c|c|c|}
\hline Results & Top tier & Middle tier & Bottom tier \\
\hline Overall & $\begin{array}{l}\text { Norway, Sweden } \\
(69)\end{array}$ & $\begin{array}{l}\text { Finland, Netherlands, } \\
\text { Denmark (64-61) }\end{array}$ & $\begin{array}{l}\text { Spain (46), } \\
\text { France (38) }\end{array}$ \\
\hline $\begin{array}{l}\text { Listening } \\
\text { comprehension }\end{array}$ & $\begin{array}{l}\text { Sweden, Norway } \\
(>70)\end{array}$ & $\begin{array}{l}\text { Denmark, } \\
\text { Netherlands, Finland } \\
(65-60)\end{array}$ & Spain, France $(<40)$ \\
\hline $\begin{array}{l}\text { Language } \\
\text { correctness }\end{array}$ & $\begin{array}{l}\text { Finland, Norway, } \\
\text { Netherlands, } \\
\text { Sweden (68-64) }\end{array}$ & $\begin{array}{l}\text { Spain, Denmark } \\
(59-54)\end{array}$ & France (48) \\
\hline $\begin{array}{l}\text { Reading } \\
\text { comprehension }\end{array}$ & $\begin{array}{l}\text { Sweden, Norway, } \\
\text { Finland }(86-80)\end{array}$ & $\begin{array}{l}\text { Denmark, Netherlands } \\
(78-77)\end{array}$ & $\begin{array}{l}\text { Spain (64), } \\
\text { France (57) }\end{array}$ \\
\hline $\begin{array}{l}\text { Written } \\
\text { production }\end{array}$ & $\begin{array}{l}\text { Norway, Sweden } \\
(<60)\end{array}$ & $\begin{array}{l}\text { Finland, Denmark, } \\
\text { Netherlands }(<50)\end{array}$ & $\begin{array}{l}\text { Spain }(<30) \text {, } \\
\text { France }(<20)\end{array}$ \\
\hline
\end{tabular}

Note: Figures in brackets indicate correct answers in percentages.

The positive attitudes among the Swedish high-school students support earlier research results, which have shown that Swedes in general are very well disposed towards English (Oakes, 2001; Wingstedt, 1998), and this observation is particularly true of younger generations. For example, in his comparative study on language and national identity in France and Sweden, Oakes (2001) found that young Swedes reported much more positive attitudes towards English than their French counterparts. They even rated English as more adapted to modern society and as more beautiful than Swedish. Such attitudes also work in tandem with perceived skills and Oakes suggests that being good at English is indeed part of a Swedish national identity. Frequent code-switches to English, particularly among the young, can also be linked to positive perceptions of English where the use of English can be a means of constructing an identity as a member of an urban, global community. Similar findings have also been reported for Denmark, with abundant use of English being a characteristic feature of youth language (Preisler, 2003).

A recent study on the use of and attitudes towards American and British English accents among Norwegian adolescent learners (Rindal, 2010) indicates a high level of English proficiency in that the students managed to exploit the two English varieties for their own purposes of self-presentation. It was found that most students preferred British English pronunciation for more formal and school-oriented interactions, whereas American English was favoured in informal contexts and peer-group interactions. Rindal (2010: 255) argues that 'learners create social meaning through stylistic practice by choosing from the English linguistic resources available' and that the 
findings 'give strong indications that the learners make use of L2 in their construction of identity'.

\section{Skills and attitudes among Scandinavians in general: The Eurobarometer}

Results from the Eurobarometer survey of language skills of Europeans (EC, 2006) show that the overwhelming majority of Scandinavian respondents speak at least one other language in addition to their first language (see Table 1.2).

The results for the Scandinavian members of the EU are, as can be seen from Table 1.2, significantly above the EU average, based on the 25 member states at the time of polling (results for the UK, which displayed the lowest command of other languages, have also been included for comparison). As many as $90 \%$ of Swedish respondents report they know one foreign language well enough to have a conversation in that language.

Setting aside first language speakers of English, the language that most respondents say they are able to have a conversation in is, not unexpectedly, English (see Table 1.3). It is also worth noting that the dominance of English is particularly pronounced in Sweden. There, the tendency to invest in one language is stronger than in the other Scandinavian countries, where many more also say they can have a conversation in at least two languages in addition to their first language (see Table 1.2).

Overall, respondents from all $25 \mathrm{EU}$ countries are very positive towards knowledge of foreign languages. Most positive are the Swedes, where 99\% agree with the statement 'Do you think knowing other languages than your mother tongue is, or could be, very useful ... for you personally?', with $97 \%$ of respondents saying English is the most useful language. These results are almost identical to the Swedish Grade 9 students' positive evaluation of the usefulness of knowing English (98\%).

So far the overview points to the widespread knowledge of English in Scandinavia where English language proficiency is regarded as something positive, in particular for international contacts and cross-cultural

Table 1.2 Which languages do you speak well enough to be able to have a conversation excluding your mother tongue? (percentage of respondents)

\begin{tabular}{lllll} 
Country & One language & Two languages & Three languages & None \\
\hline EU (25) & 56 & 28 & 11 & 44 \\
\hline Sweden & 90 & 48 & 17 & 10 \\
\hline Denmark & 88 & 66 & 30 & 12 \\
\hline Finland & 69 & 47 & 23 & 31 \\
\hline UK & 38 & 18 & 6 & 62 \\
\hline
\end{tabular}

Source: Special Eurobarometer 243 (EC, 2006). 
Table 1.3 The most widely known languages (percentage of respondents)

\begin{tabular}{|c|c|c|c|c|c|c|}
\hline \multirow{2}{*}{$\frac{\text { Country }}{\text { EU (25) }}$} & \multicolumn{2}{|c|}{ Language 1} & \multicolumn{2}{|c|}{ Language 2} & \multicolumn{2}{|c|}{ Language 3} \\
\hline & English & 38 & French & 14 & German & 14 \\
\hline Sweden & English & 89 & German & 30 & French & 11 \\
\hline Denmark & English & 86 & German & 58 & French & 12 \\
\hline Finland & English & 63 & Swedish & 41 & German & 18 \\
\hline UK & French & 38 & German & 9 & Spanish & 8 \\
\hline
\end{tabular}

Source: Special Eurobarometer 243 (EC, 2006).

communication. Being good at English, as noted above, even seems to be a marker of national identity, at least for young Swedes (Oakes, 2001). These are factors that all promote the use and increased spread of English. As outlined in the next section, debate about the role of English in Scandinavian countries has mainly concerned the rapid spread of English in certain domains, where concerns have been raised that the high level of proficiency might prove to be a threat to the long-term survival of the national languages.

\section{English in the Domains of Higher Education and Research in Sweden}

The following section examines the role of English in the domains of higher education and research, and explores the link between the actual linguistic situation and language policy and planning, using Sweden as an example.

Transnational student movements in an increasingly global education market have led to significant increases in the number of international students enrolled at Swedish universities. In 10 years the number of international students tripled to 36,600 (2008/2009 academic year), which means that one in four newly enrolled students was an international student. No doubt this development is linked to the high number of courses and programmes offered in English: 18\% of all courses, 36\% of all Masters-level courses, 25\% of all programmes and $65 \%$ of all Masters-level programmes were offered in English (Cabau, 2011; Salö, 2010). In other words, the higher the level, the more likely that instruction takes place in English. In 2007 Sweden was in fourth position in Europe with regard to the number of programmes offered in English (123), after the Netherlands (774), Germany (415) and Finland (235) (Wächter \& Maiworm, 2008). However, by 2008 the number of programmes offered in English in Sweden had increased exponentially to 530 (Cabau, 2011). These figures lend support to the argument that the globalisation of higher education has led to increased linguistic uniformity across Europe, as more and more countries offer courses taught in English to attract international students (Graddol, 2006: 77). 
The large number of courses and programmes offered in English, however, does not necessarily mean that English is always used. On the one hand, Swedish is often used, to some extent, in subjects that are advertised in the university handbook as being offered in English. Söderlundh (2010) investigated the use of Swedish in university courses offered in English with a large proportion of international students. She studied language choice both in the classroom and in more socially oriented contexts during breaks. Her results show that Swedish-speaking students often use Swedish among themselves in group work and when addressing the teacher. Also, if no nonSwedish speakers are present in the classroom, interaction usually shifts to Swedish. On the other hand, subjects advertised as being offered in Swedish are not 'islands of Swedish', as the required reading is often partly in English.

As the language of research dissertations, English has increased its share significantly and is now completely dominant. For example, in 1920 about $15 \%$ of all doctoral theses were written in English, in 1960 its share had increased to $70 \%$, and in 2008 87\% were written in English. During the same period, the use of Swedish for doctoral theses steadily decreased from $50 \%$ in 1920 to $12 \%$ today. However, it is worth noting that the use of English is very unevenly distributed between disciplines, with $94 \%$ of theses in natural sciences written in English compared to only 38\% for the humanities. The reason for the high overall figure is that the vast majority of all theses are written in natural sciences (for statistics, see Cabau, 2011; Salö, 2010).

The increased use of English in research can be seen as a means for smaller language communities to participate in international scientific communication, and in this role the use of English is not questioned per se. The significant increase of English in higher education is also clearly linked to student mobility and the language needs of international students. This, in turn, potentially leads to tension within the domestic market and its needs, which we now turn to.

\section{Domain loss?}

A dominant discourse over the past decade has been about the strong position of English in Sweden. In particular, the debate has concerned domain loss (e.g. Gunnarsson, 2001; Melander, 2001). For example, the English version of the website of the Swedish Language Council (Språkrådet, n.d.) states that 'English has started to compete with Swedish in a growing number of fields in Swedish society - in large, international companies, in the educational system and in the media industry'.

It has been argued that decreased use of Swedish in a particular domain is the first step towards a loss of that domain to English (e.g. Melander \& Thelander, 2006). With decreasing use it will also be more difficult to make full use of Swedish in related domains, and domain-loss proponents argue that loss of one domain will, inevitably, spread to other domains. 
Although few would argue seriously that Swedish is destined for extinction, many have interpreted the risk of domain loss as a warning sign - if no action is taken now, a diglossic situation will be reached where English is used in the public domain with Swedish limited to the private domain. Such a development would undermine democratic values, as those with limited English skills would not have full access to all domains in society (e.g. Josephson, 2004).

The debate on domain loss in favour of English thus provides an impetus for taking action through language policy and planning. The recent Swedish Language Act (Swedish Ministry of Culture, 2009) described below, which makes Swedish the 'principal language' of Sweden, could be interpreted against the background of fear of domain loss. However, some researchers challenge the domain loss theory. According to Boyd (2011), a certain domain does not have to be either English or Swedish, but both languages can be used side by side within it. Further, there is no firm evidence that loss of a language in a particular domain creates a domino effect, where other domains are necessarily affected (Boyd \& Dahl, 2006).

\section{(Re)actions 1: The Language Act}

The Swedish Language Act came into effect in 2009, after over a decade of preparatory work, dating back to the Draft Action Programme for the Promotion of the Swedish Language (Språkrådet, 1998) commissioned by the Swedish Government and drawn up by the Swedish Language Council. (For further background on the Language Act see, for example, Boyd, 2011; Norrby, 2008.) The Language Act regulates the principles that were passed by Parliament in 2005 , and specifies the 'position and usage of the Swedish language and other languages in Swedish society' and intends to 'protect the Swedish language and language diversity in Sweden, and the individual's access to language' (Language Act, Section 2). The Act states the following objectives for the position of Swedish in Sweden (Sections 4-6):

Swedish is the principal language in Sweden

As principal language, Swedish is the common language in society that everyone resident in Sweden is to have access to and that is to be usable in all areas of society

The public sector has a particular responsibility for the use and development of Swedish.

Furthermore, the Act regulates language use in the public sector, stating that: 'the language of the courts, administrative authorities and other bodies that perform tasks in the public sector is Swedish' (Section 10). Finally, 'Swedish is the official language of Sweden in international contexts' (Section 13). In 
regard to the individual language user, the Act specifies that '[a]11 residents of Sweden are to be given the opportunity to learn, develop and use Swedish' (Section 14).

It could be argued that the Language Act simply states what is obvious to everybody who lives in Sweden, namely, that Swedish is spoken by the vast majority, either as a first or second language. However, making this explicit through legislation can be interpreted as a symbolic act to safeguard the position of Swedish as the common language at a time where there is a perceived threat from the outside. It is, however, interesting to note that there is no specific reference made in the Language Act to the use of English in Sweden, although it is no exaggeration to say that some of the impetus for the legislation is the increased role of English in some domains, such as in higher education (Cabau, 2011; Norrby, 2008).

\section{(Re)action 2: University language policy}

In recent years, an increasing number of universities in Scandinavia have begun to address the language situation in higher education, and several universities now have language policies in place. The first university in Sweden to implement such a policy was the University of Gothenburg, whose language policy (University of Gothenburg, n.d.) includes several provisions that are clearly consonant with the provisions of the Language Act. The decision to establish a language policy for the university was made by the University Board in 2006, and in 2010 the Vice-Chancellor made provisions for its implementation through the University's Action Plan for Language Issues 2010-2012 (University of Gothenburg, 2010). For example, the language policy of the university states that 'Swedish should be the main language of teaching in first cycle courses (Bachelor level) unless it is necessary to use another language, such as in foreign language courses', that 'dissertations in languages other than Swedish are to include extensive summaries in Swedish', and that 'all the scientific fields of the university should endeavour to use adequate terminology in Swedish' (University of Gothenburg, 2010: 6). Demanding Swedish summaries of theses, for example, is one way of safeguarding the continued use and development of appropriate terminology in Swedish - a direct response to the fear of domain loss.

While the policy aims at promoting the use of Swedish for the domestic market, however, the tone is quite different in relation to the international market, where the aim is to position the university as an attractive destination for students, researchers and teachers from outside Scandinavia by widespread use of English, both at undergraduate and postgraduate levels (University of Gothenburg, 2010: 8):

The number of courses in which English is used as the language of teaching ... should, therefore, increase to encourage mobility and heighten the 
quality of research and education according to the objectives of the Bologna Process.

Use of English at the undergraduate level - in set texts and in the classrooms is not simply seen as a service to incoming international students, but as equally important for enhancing the English comprehension skills of local students and preparing them for higher levels of study, where English is used more extensively. At the postgraduate level (Masters and doctoral levels) and in research, the use of English should be even more prevalent in order to facilitate mobility - both in terms of increased numbers of incoming international students and researchers as well as outgoing Swedish students and researchers who wish to study abroad or engage with the international research community (see University of Gothenburg, 2010: 8).

There are clear tensions between the domestic and international policy statements, as seen in the quotations above, and the same language policy can have conflicting objectives as it tries to combine domestic demands for strengthening Swedish with the increasing internationalisation of higher education, and hence the use of English. Typically, the national language (Swedish) is promoted at the undergraduate level, in particular at lower levels, in courses aimed at the domestic market and Swedish students, whereas English is promoted at the postgraduate level, but also to some extent in advanced undergraduate-level courses, and in courses aimed at the international market more generally.

The successful implementation of the language policy and its call for increased use of English naturally depends on the cooperation of teaching staff, and here the policy simply states that '[a]11 teaching staff should be prepared to teach in English or at least teach bilingually with visual support in English' (University of Gothenburg, 2010: 9). What is implicit in such a statement is that all Swedish university teaching staff are indeed capable of switching to English, or teaching bilingually - an assumption that might not prove correct in reality. As already noted, Söderlundh (2010), for example, found that Swedish was used to varying extents in university courses offered in English. While we do not know the teaching staff's actual ability to teach in English (with no or little effort), the policy statement certainly demonstrates the belief that the university's teachers can be considered as bilingual or at least very competent second language users of English.

\section{English in the City Streetscape}

Linguistic landscaping is a relatively new subdiscipline of sociolinguistics. It involves the documentation of language use in public signs and public writings in urban spaces and seeks to understand the relationships between different languages and their users in multilingual societies (see contributions 
in Shohamy et al., 2010). Linguistic landscaping can involve any language, but the presence and increased predominance of English in urban spaces is often a part of such documentation (see, for example, Hult, 2003 for a survey of English signs in urban Sweden).

For the purpose of illustrating to what extent English permeates the urban streetscape in Scandinavia, I have documented the use of English in Gallerian, a large shopping mall with 80 shops, cafés and restaurants in the centre of Stockholm. On average, four out of five shop windows had signage in English with sale being the most frequently used word. The displacement of Swedish rea (short for 'realisation') in favour of the English sale has been quick and only a few years ago the Swedish word was by far the most common sight. A similar tendency has been reported in a German context with sale increasingly replacing the German Ausverkauf in Berlin shop windows (Papen, 2012: 66). Papen suggests that this could be explained by the English word carrying more modern connotations and also that sale is much shorter than the German counterpart. In the Swedish context, only the former explanation might hold true as the Swedish word for sale involves only three letters.

Only a minority of shops had all their shop window signs in Swedish. Instead, in the majority of cases, the use was mixed with signs including both languages as shown in Figure 1.1. In this case, the use of English is

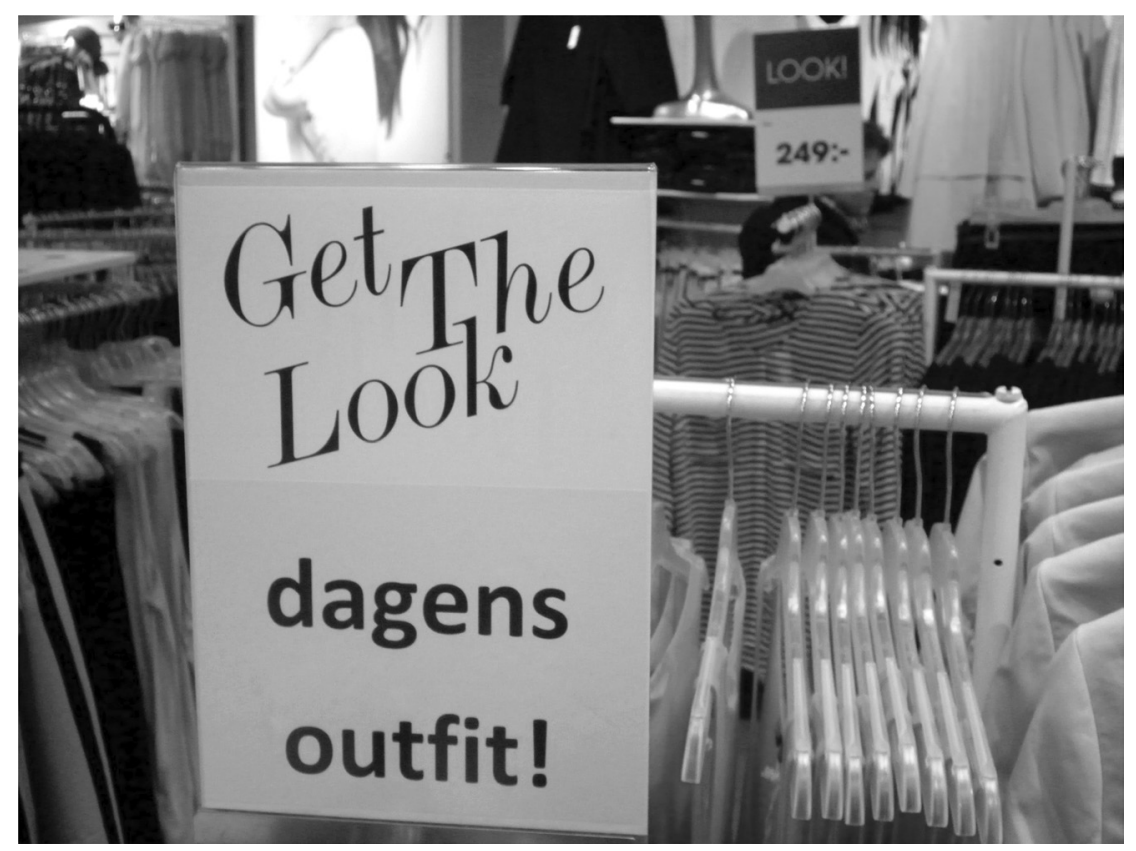

Figure 1.1 Simultaneous use of English and Swedish in shop signs 
limited to a catchy phrase, 'Get the look', followed by a language mixture in 'dagens outfit!' ('the outfit of the day!' or 'the outfit of today!').

Other similar phrases used include Get the style! and Nine decades of fashion from two shops selling women's clothing and underwear, respectively. Signs like these serve the purpose of conveying a certain mood, and are emblematic rather than necessary for successful shopping. There are, however, shops in which not only shop frontage signs are in English but where important information about models and sizes, etc., is also in English only, as in the Levi's shop where the following information appears on a placard in the shop (see Figure 1.2):

Levi's Curve ID is a new fit system created after we listened to women from around the world and analysed more than 60,000 body scans to better understand their shape, proportion and size. Our research team confirmed what we've known all along: one 'fit' does not flatter all women. Levi's* Curve ID are three quintessential fits for women corresponding to three distinct body types: Slight Curve, Demi Curve and Bold Curve. These fits are based on the difference between your seat and hip measurements. This new fit solution gives every woman a pair of jeans that loves her body, based on shape not size.

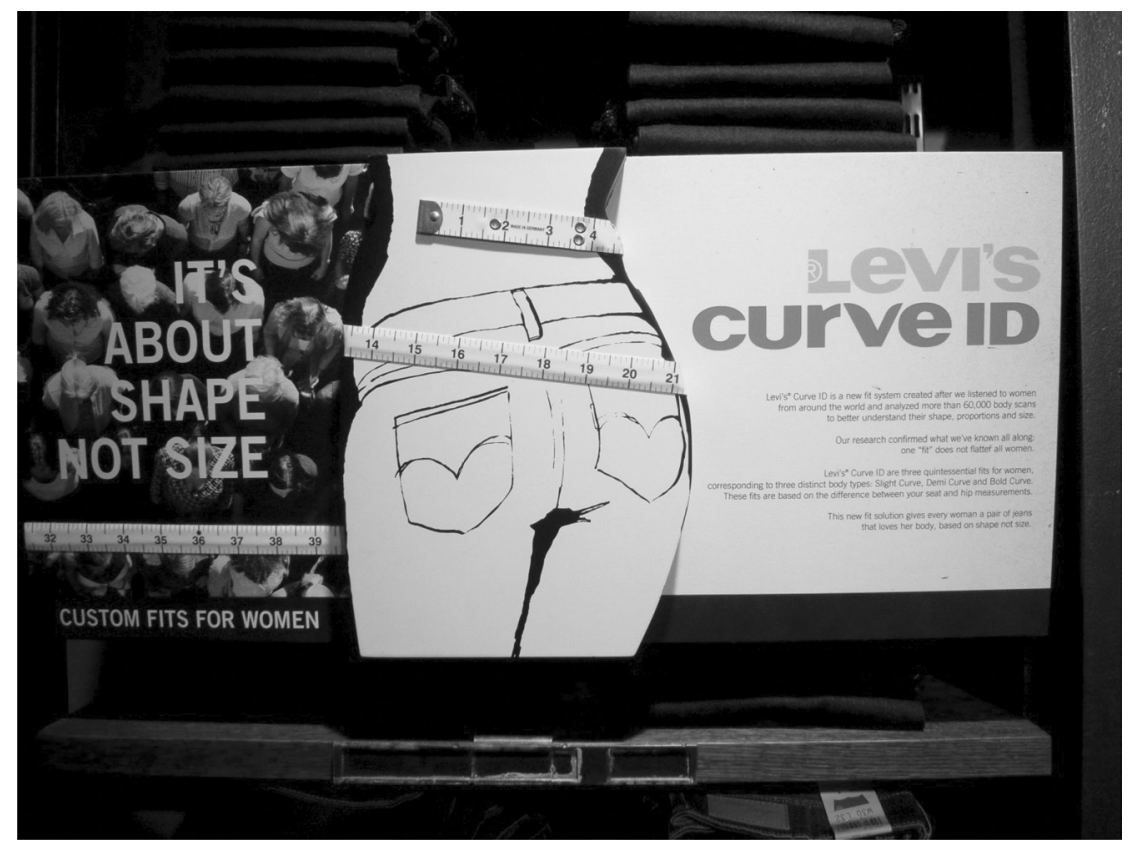

Figure 1.2 Information sign in English 
Companies want to sell their products, and the use of English must be seen in light of this. If the use of English in the shopping mall had been limited to catchy phrases or isolated words in an otherwise Swedish context, the obvious conclusion would be that English served primarily to create a certain mood or feeling, not so different from adolescents code-switching to English as an act of identity. But we are faced with much more far-reaching use of English, which rests on the assumption that shoppers have reasonable command of English - otherwise it would be pointless for companies to promote their wares solely in English. The use of English cannot be explained by the presence of international tourists in the city of Stockholm, as a similar use of English signs is found in shopping malls in other, less central locations. Furthermore, many of the shops in Gallerian belong to large chains and their use of English is uniform across Sweden.

\section{Conclusion}

There is a significant tension between contrasting trends of accepting and controlling the role of English in Scandinavia today, as seen in the Swedish examples discussed above. On the one hand, there is the influential debate in language policy quarters about the fear of domain loss, which has formed an important background - albeit implicitly - to the recent Swedish Language Act (2009). The Act and the political debate that preceded legislation (see, for example, Boyd, 2011; Norrby, 2008) have certainly put the linguistic situation and the role of the national language on the agenda. However, official or public statements about safeguarding Swedish against the increased use of English might not have much of an effect on the population at large, as pointed out by Melander (2006) and others (e.g. Boyd \& Huss, 2004). In fact, the linguistic reality and attitudes of people in general suggest a much more accepting stance towards English in Scandinavia. The high level of proficiency in English, paired with very positive attitudes, is a factor that promotes further use of English. For example, the high incidence of code-switches to English in conversation, particularly among the young, displays how use of English is an act of identity and a resource for signalling membership in a global (youth) culture (see, for example, Preisler, 2003; Sharp, 2001). Furthermore, the strong presence of English in the linguistic landscape - in shops and restaurants, not just in Stockholm but throughout Scandinavia - shows that English is seen as a positive asset for attracting customers. If shop owners believed that the general public viewed the use of English negatively, they would of course stop such a language practice immediately.

The tension between accepting and controlling perspectives is perhaps never more apparent than in the higher education sector. In courses aimed at the international market, English is not only accepted, but is regarded as a necessary instrument for attracting students from abroad, although the 
majority of international students in Sweden and other Scandinavian countries do not come from an English language background. The significance of English is obvious from overall statistics on the number of courses and programmes offered in English, as well as from statements in university language policy documents. For the Swedish domestic market the situation is different, however. Here, the tendency is ostensibly towards promoting Swedish and controlling the role of English, such as through university language policy which states that Swedish should be the principal language for teaching in undergraduate courses.

To return to the question posed in the title of this chapter - whether English is monster or mate - the answer is that it depends on whom you ask. There are tensions between different perspectives, on the one hand, of accepting and promoting English, and on the other, of controlling its use through language policy and legislation. However, while English is everywhere in Scandinavia, the national languages are hardly doomed. On the contrary, they are strong languages in the sense that they are highly codified with dictionaries, grammars and a rich national literature, as well as being the languages of officialdom and widely spoken. From such a position, there is hardly reason to believe that English is the monster ready to devour the national languages. It is, however, more likely that we will see more extensive parallel use of languages - a national language side by side with English in a particular domain, rather than domain loss. Such use would promote a higher level of individual bilingualism and counteract 'the monolingual mindset' (Clyne, 2005: 21) that permeates some quarters of national language policy and planning, as seen in the passing of Sweden's Language Act. In other words, it is not a question of, say, Swedish or English, Danish or English, but of both.

\section{References}

Ben-Rafael, E., Shohamy, E. and Barni, M. (2010) Introduction: An approach to an 'ordered disorder'. In E. Shohamy, E. Ben-Rafael and M. Barni (eds) Linguistic Landscape in the City (pp. xi-xxviii). Bristol: Multilingual Matters.

Bonnet, G. (ed.) (2002) The Assessment of Pupils' Skills in English in Eight European Countries. Paris: European Network of Policy Makers for the Evaluation of Education Systems. See http://www.eva.dk/projekter/2002/evaluering-af-faget-engelsk-i-grundskolen/projekt produkter/assessmentofenglish.pdf.

Boyd, S. (2011) Do national languages need support and protection in legislation? The case of Swedish as the 'principal language' of Sweden. In C. Norrby and J. Hajek (eds) Uniformity and Diversity in Language Policy: Global Perspectives (pp. 22-36). Bristol: Multilingual Matters.

Boyd, S. and Dahl, Ö. (2006) Grundlöst om språkdöd [Groundless on language death]. Språkvård 4, 36-40.

Boyd, S. and Huss, L. (2004) Do the national languages of Europe need a national language policy? Some reflections on the report of the Committee for the Advancement of Swedish from a multilingual perspective. In A.M. Lorenzo Suárez, F. Ramallo and $X$. Rodriguez-Yanez (eds) Proceedings of the Second International Symposium on Bilingualism (pp. 841-856). Vigo: Servizo de publicacións da universidade de Vigo. 
Cabau, B. (2011) Language policy in Swedish higher education. A contextual approach. European Journal of Language Policy 3 (1), 37-60.

Clyne, M. (2005) Australia's Language Potential. Sydney: University of New South Wales Press.

Delsing, L. and Lundin Åkesson, K. (2005) Håller språket ihop Norden? En forskningsrapport om ungdomars förståelse av danska, svenska och norska [Does language hold the Nordic region together? A research report of adolescents' understanding of Danish, Swedish and Norwegian]. Copenhagen: TemaNord. See http://www.norden.org/da/publikationer/ publikationer/2005-573/.

EC (2006) Europeans and their Languages. Special Eurobarometer 243. Brussels: European Commission. See ec.europa.eu/public_opinion/archives/ebs/ebs_243_en.pdf.

Graddol, D. (2006) English Next. Why Global English May Mean the End of 'English as a Foreign Language'. London: British Council. See http://www.britishcouncil.org/ learning-research-english-next.pdf.

Gunnarsson, B. (2001) Swedish tomorrow - a product of the linguistic dominance of English? In S. Boyd and L. Huss (eds) Managing Multilingualism in a European NationState. Challenges for Sweden (pp. 51-69). Clevedon: Multilingual Matters.

Haugen, E. (1972) Semicommunication: The language gap in Scandinavia. In S.A. Dil (ed.) The Ecology of Language. Essays by Einar Haugen (pp. 215-236). Stanford, CA: Stanford University Press.

Hult, F.M. (2003) English on the streets of Sweden: An ecolinguistic view of two cities and a language policy. Working Papers in Educational Linguistics 19 (1), 43-63.

Josephson, O. (2004) Inledning. Engelskan i Sverige. Språkval i utbildning, arbete och kulturliv [Introduction. English in Sweden. Language choice in education, work and culture]. In O. Josephson and K. Jämtlid (eds) Engelskan i Sverige. Språkval $i$ utbildning, arbete och kulturliv (Småskrift utgiven av Svenska språknämnden 2004) (pp. 7-24). Stockholm: Norstedts Ordbok.

Melander, B. (2001) Swedish, English and the European Union. In S. Boyd and L. Huss (eds) Managing Multilingualism in a European Nation-State. Challenges for Sweden (pp. 13-31). Clevedon: Multilingual Matters.

Melander, B. (2006) Funktion eller kultur - vad ska svensk språkpolitik syfta till? [Function or culture - what are the aims of the Swedish language policy?] In Språk i Norden (pp. 43-55). Oslo: Nordic Language Council.

Melander, B. and Thelander, T. (2006) Så tar man livet av ett språk [How to kill a language]. Språkvård (2), 39-42.

Norrby, C. (2008) Swedish language policy: Multilingual paradise or utopian dream? In J. Warren and H. Benbow (eds) Multilingual Europe: Reflections on Language and Identity (pp. 63-76). Newcastle upon Tyne: Cambridge Scholars Publishing.

Oakes, L. (2001) Language and National Identity. Comparing France and Sweden. Amsterdam: John Benjamins.

Papen, U. (2012) Commercial discourses, gentrification and citizens' protest: The linguistic landscape of Prenzlauer Berg, Berlin. Journal of Sociolinguistics 16 (1), 56-80.

Preisler, B. (2003) English in Danish and the Dane's English. International Journal of the Sociology of Language 159, 109-126.

Rindal, U. (2010) Constructing identity with L2: Pronunciation and attitudes among Norwegian learners of English. Journal of Sociolinguistics 14 (2), 240-261.

Salö, L. (2010) Engelska eller svenska? En kartläggning av spräksituationen inom högre utbildning och forskning [English or Swedish? A survey of the language situation in higher education and research]. Stockholm: Språkrådet.

Sharp, H. (2001) English in Spoken Swedish. A Corpus Study of Two Discourse Domains. Acta Universitatis Stockholmiensis. Stockholm Studies in English XCV. Stockholm: Almqvist \& Wiksell International.

Shohamy, E., Ben-Rafael, E. and Barni, M. (eds) (2010) Linguistic Landscape in the City. Bristol: Multilingual Matters. 
Söderlundh, H. (2010) Internationella universitet - lokala språkval: Om bruket av talad svenska i engelskspråkiga kursmiljöer [International universities - local language choices: On spoken Swedish in English-medium course environments]. Skrifter utgivna av Institutionen för nordiska språk vid Uppsala Universitet No. 83. Uppsala: Department of Scandinavian Languages.

Språkrådet (Swedish Language Council) (1998) Draft Action Programme for the Promotion of the Swedish Language. Stockholm: Swedish Language Council. See http://www. sprakradet.se/2444.

Språkrådet (Swedish Language Council) (n.d.) New website for living languages and traditions. See http://www.sprakradet.se/international.

Swedish Ministry of Culture (2009) Swedish Language Act. Swedish Code of Statutes No. 2009:600. Summary in English. See http://www.eui.eu/Projects/InternationalArt HeritageLaw/Documents/NationalLegislation/Sweden/languageact.pdf.

University of Gothenburg (2010) Action Plan for Language Issues 2010-2012. Gothenburg: University of Gothenburg. See http://www.gu.se/english/cooperation/international cooperation/international-initiatives/language-initiatives/action-plan-for-language/.

University of Gothenburg (n.d.) Language Policy for Göteborg University. See http://www. gu.se/digitalAssets/1340/1340549_language-policy.pdf.

Wächter, B. and Maiworm, F. (2008) English-Taught Programmes in European Higher Education. The Picture in 2007. ACA Papers on International Cooperation in Education. Bonn: Lemmens.

Washburn, L. (1997) English Immersion in Sweden. A Case Study of Röllingby High School 1987-1989. Stockholm: Department of English, Stockholm University.

Wingstedt, M. (1998) Language Ideologies and Minority Language Policies in Sweden. Stockholm: Centre for Research on Bilingualism, Stockholm University. 